\title{
THE EFFECTIVENESS OF SCHOOL EDUCATION - FEATURED IMPLICATIONS CONSIDERATIONS
}

\author{
Tomasz Prauzner \\ Institute of Technology and Safety Systems, \\ Jan Dlugosz University in Czestochowa, Poland
}

\begin{abstract}
The main objective of the paper is to argue for a multidimensional character of effectiveness of school education and to discuss a number of factors that influence the outcome of education directly or indirectly. Assessing the effectiveness of school education sheds light on its current problems and indicated directions for future research on innovative approaches to solving such problems.
\end{abstract}

Keywords: teaching, the effectiveness of education, modern teaching aids.

\section{Effectiveness of schooling - preliminary analysis}

Effectiveness of school education is a highly complex issue. It has been addressed in a number of publications, for example by professor Kazimierz Denek, who assumes a broad perspective when dealing with effectiveness and his works can be an inspiration for further analyses. Effectiveness of schooling can be defined in a number of ways. The multifaceted character of effectiveness is a consequence of a new approach to education as a domain which is at the same time formalised and informal. The most widespread definition of effectiveness attested in the literature evokes the idea of a teacher's and student's didactic practice being successful. (Denek, 2011) This kind of perspective is however quite superficial as it does not take into account a number of factors, both overt and covert, having a direct on indirect impact on schooling effectiveness. Because of this, following the above-mentioned author's considerations, I prepared a graphical representation of the problem, which in my opinion, offers a more lucid illustration that a descriptive form (Fig. 1). The diagram draws attention to the variety of components and invites a subjective reflection on the problem. It points to the fact that there are numerous correlated factors affecting the education process. (Bereźnicki, 2007; Kupisiewicz, 2005). Effectiveness of schooling can be seen as a multivariable function, as was pointed out in the works of Franciszek Bereźnicki, Wincenty Okoń, Małgorzata Wieczorek-Tomaszewska and others. 


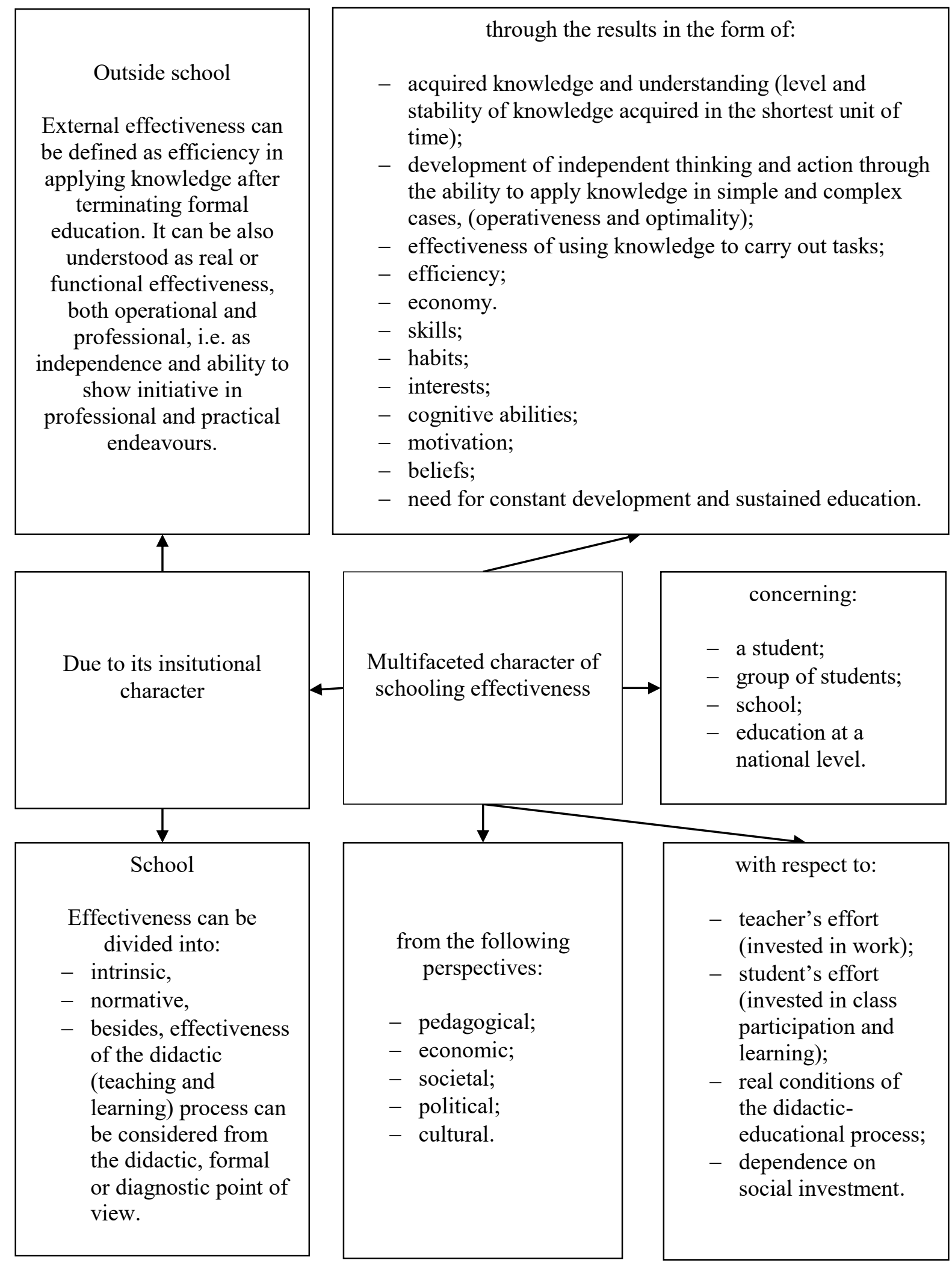

Fig.1 Multifaceted character of schooling effectiveness (based on Denek 1997) 


\section{Effectiveness of education vs. the current model of school}

An interesting viewpoint on current problems of school education was presented by the renowned British philosopher, educational expert, writer and world-acclaimed authority on creativity, innovation and human resources Ken Robinson. He described the currently functioning educational system in a highly convincing and appealing way, by analysing it in the framework of philosophy, sociology and economics. (Robinson, 2010) The main message of these analyses is "Education needs revolution, not evolution".

The author's reflections provide a very faithful and adequate account of the current educational system and its effectiveness. The main criticism against it is that its structure is outdated and unsuitable for the present-day social expectations and demands. As the author points out, “,...we are confronted with a new situation, so we have to act and think accordingly..., we have to liberate ourselves from the existing dogmas from the tranquil past, which do not fit the turbulent present. There are few opportunities for a change, so if there is one, we have to grab it." This thought is quoted after Abraham Lincoln (1862) but it still appeals to modern people and is relevant for the present topic. Robinson also observes that the current educational system perpetuates patterns that originated in the industrial era, the main aim of which was to support the production of goods, and which promoted linearity, conformism and division of individual into social classes. All children are assigned to classes only on the basis of the age criterion (by analogy to the "best before date" on products) and the educational process is shaped in a synchronous frame with fixed stages (as the production cycle in a manufacture). The school is becoming increasingly unified and standardised identical curricula and examinations. As Robinson puts it, “...we are slaves to ideas that we consider obvious, natural and stable...". The author suggests that a new pattern should be adopted, analogous to agriculture, where growth is not seen as a mechanical but organic process, the outcome of which may be difficult to predict, yet the farmer is responsible for providing conditions conducive to growth. This metaphor represents the model that should be implemented in education, which should be personalised to match an individual learner's personality and potential. This task should be undertaken by teachers, who are responsible for designing and practical implementation of solutions offering teaching on an individual basis. The challenge of this task can be faced by talented teachers with open minds, who are not afraid of innovations and who are familiar with information technology, using Internet and multimedia applications. A student at any stage of the education process should be treated as a member of society with which he/she will cooperate using a variety of his/her assets (and not just one). Another point raised by the author is that education operates only on "the upper part of the body". This means that priority is given to science, 
especially maths and foreign languages whereas art is very much neglected. What is subject of education is not the body as a whole but only the mind. The body is only a carrier of the mind, which is considered the centre of human intelligence. An individual's mental resources are decisive in classifying him/her as intelligent or not. As is emphasised by the author, most of the important inventions that revolutionised the world were contributed by geniuses who did not hold a university degree but who were creative and capable of connecting facts. The key to success is therefore creativity and not knowledge resources. These considerations make it evident that the role of philosophical trends known as constructivism and connectivism is increasingly recognised. Discoveries made within the cognitive science also play a significant role. Besides, the recent development of neurodidactics sheds new light on the assessment of an individual's features impacting on his/her cognitive skills. (Prauzner, 2016)

Much criticism levelled against the current education model stems from the fact that the primary aim of present-day schooling is to provide a young person with a certain amount of information, the usefulness of which may be dubious after some time. Considering the speed of changes in the world, it is difficult to make definite predictions concerning the validity and usefulness of knowledge resources. It is likewise difficult to anticipate which disciplines of studies will be given priority in the future. The didactic process has to be constantly modernised and the school should prepare students to face challenging situations, the exact circumstances of which cannot be defined or predicted at this moment, rather than offer a certain amount of encyclopaedic information. The basis for promoting creativity is multidirectional and divergent thinking, enabling a student to notice a number of possible solutions, as opposed to linear or convergent thinking. To develop the skill of divergent thinking, it is necessary to work in a group and learn to cooperate. Most products or ideas nowadays are created collectively and not by an effort of an individual. Since every member of the group contributes creativity of a different type, the effect can be achieved. In this way, collective work enhances the skills of an individual and contributes to achieving a desirable effect thanks to joint ideas at the same time. In this kind of innovative approach to education, a new question arises concerning educational policy and the assessment of its effectiveness. (Ptak, 2016) One of the ways of implementing a new system of education is adopting a pragmatic model based on the assumption that the subject of education should include all such content that is likely to be useful as input for creating new ideas in the future. In the light of innovative information and computer technologies, new methodological solutions become available in the educational system. Modern didactic aids and methods can offer new possibilities of experimenting in the educational space, the examples being new multimedia programmes or deterministic computer simulations employed in technical education and in other disciplines. (Ptak \& Prauzner, 2011) 
Turning again to the considerations offered by Robinson, there are two types of thinking that can be distinguished: divergent and convergent. The former is related to what is known as fluid intelligence, i.e. the type of intelligence that affords an individual's adaptation to a specific problem. The author believes that fluid intelligence decreases with age, and explains this as a result of the inhibitory effect of the educational system in its current shape. A new system of education should therefore be based on new practical didactic solutions so that a student would be able to find information, verify its source and to be able to understand and utilise this information. (Ptak, 2015) As is evident, the fundamental effect of institutional schooling should be the effectiveness of education.

There are a variety of educational models distinguished in didactics on the basis of their form and attractiveness. It is noted that each method can be suitable for dealing with a specific situation. Methods can be modified and combined within one class unit in order to increase the effectiveness of education. Especially interesting in this respect are information-processing models, social models, personality models and behavioural-cybernetic models. A common property of these models is that they present a human being as subject with its own individual cognitive predispositions who at the same time participates in interactions with the social environment. Besides, special significance of communication is underscored, together with the fact that the precondition for successful communication is the mutuality of experience and cooperation. Communication techniques are recognised as an important element of educational models. They are thought of not only in terms of a variety of forms of communication but also in terms of didactic means fostering the development of the cognitive system. (Kozík, Noga, \& Depešová, 2015) The main criterion deciding about the choice of the teaching method is the didactic result achieved, i.e. the knowledge gained by the student. For the didactic viewpoint, the more varied the methods, the better effect can be expected. (Noga, 2009) Besides, the student can be trusted to be able to assess whether a method is attractive and effective for him/her. In the didactic process, the knowledge in the student's mind is reconstructed. Being aware of this, cognitive psychology and general pedagogy jointly point to the complexity of the notion of knowledge and its dependence on the personal cognitive, emotional as well as socio-cultural factors. (Joyce, Calhoun, \& Hopkins, 1999)

According to Wieczorek-Tomaszewska, the main problem of education in the era of the Internet and wide access to technology is the lack of established teaching modern methods so that ,new technologies win over teaching methods". (Fyfe, 2011) Morbitzer, in turn, refers to the present teaching methods as "instruments of enslavement". (Morbitzer, 2013) At the same time, it is noted that at the stage of "applications and integration" (Sysło, 2003) of special importance is to integrate teaching methods with the digital world, which determines the character of the whole didactic process. (Wieczorek-Tomaszewska, 2013) 


\section{Concluding remarks}

Effectiveness of school education is a complex phenomenon and, as the diagram presented in this article indicates, it can be understood in different ways. It can be defined on the basis of various criteria but regardless of the theoretical models the most important issue for practising pedagogues is the final result of education, that is, the didactic effect. As previous research by the author has demonstrated, in the current situation of the technical schools, the most effective method for implementing a constructivist-connectivist education model is auxiliary teaching employing modern information technology. (Prauzner, 2013) This effect must reflect a pragmatic approach to the educational process by being feasible in the first place. Unfortunately, the gap between the theoretical model and its practical application it very often large, which results in low effectiveness of the process. This is pointed out in numerous opinions, such as that of Robinson cited above, reflecting the widespread opinion of many teachers. To sum up the present considerations, let us once again turn to the words of Kazimierz Denek, postulating further steps towards innovation in education: „Education for tomorrow should be based on the good school, being a place of creative, open and active education, introducing students into collective and social life, fostering the skill to actively participate in all kinds of activities and providing an individual approach to each student". (Denek, 2007)

\section{References}

Bereźnicki, F. (2007). Dydaktyka ksztatcenia ogólnego. Kraków: Oficyna Wydawnicza "Impuls".

Denek, K. (1997). Efektywność edukacji szkolnej. Studia Pedagogiczne, Zeszyt 30 [38].

Denek, K. (2007). Tatrzańskie dyskursy wokół edukacji jutra. In: Edukacja jutra. Koszczyc, T., Jonkisz, J., \& Toczek-Werner, S. (Eds.), Wrocław.

Denek, K. (2011). Teoretyczne i aplikacyjne aspekty jakości ksztatcenia akademickiego. In: Neodidagmata 33/34, Poznan.

Fyfe, P. (2011). Digital Pedagogy Unplugged, Digital Humanities Quarterly, t. 5 (3). Online: http://www.digitalhumanities.org

Joyce, B., Calhoun, E., \& Hopkins, D. (1999). Przykłady modeli uczenia sie i nauczania. Warszawa: WSiP S.A.

Kozík, T., Noga, H., \& Depešová, J. (2015). The symptoms of postmodernism in media and multimedia. In: European Journal of Science and Theology, Volume 11, Issue 6.

Kupisiewicz, C. (2005). Podstawy dydaktyki. Warszawa: WSiP.

Morbitzer, J. (2013). Szkoła na miarę XXI wieku. In: Hojnacki, L., \& Polak, M. (Eds.), In: Jakich pilnych zmian potrzebuje polska szkoła? Propozycje ekspertów. Warszawa: Think Global Sp. z o.o.

Noga, H. (2009). Sociometric methods in technological and information technology education. In: Chraska, M., \& Havelka, M. (ed.), Trends in education, Information technologies and technical education, vols 1 and 2. 
Prauzner, T. (2013). Information Technology in Contemporary Education - Individuals' Researche. American Journal of Educational Research, 2013, Vol. 1, No. 10, online, http://www.sciepub.com

Prauzner, T. (2016). Interactive computer simulation as a response to contemporary problems of technical education. In: Society. Integration. Education, Proceedings of the International Scientific Conference. Volume II, May 27th - 28th, Rēzekne, Latvia.

Ptak, P. (2015). Application of DasyLab in Teaching Electrical Engineering. In: Society. Integration. Education, Rezekne, Latvia, Vol. 4.

Ptak, P. (2016). Application of software packages in research and didactics. In: Society. Integration. Education, Rezekne, Latvia, Vol. 2.

Ptak, P., \& Prauzner, T. (2011). Zastosowanie programów komputerowych $w$ dydaktyce przedmiotów technicznych. In: Journal of Technology and Information Education, nr $1 / 2011$.

Robinson, K. (2010). Out of Our Minds: Learning to Be Creative (Wiley \& Sons). Polish Edition: Oblicza Umysłu. Ucząc się kreatywności. Wyd. Element.

Sysło, M. M. (2003). Szkoła jako instytucja ustawicznego ksztatcenia i zwiazana z tym rola technologii informacyjnej. In: Morbitzer, J. (Ed.), Komputer w edukacji. Kraków: Wydawnictwo Naukowe AP.

Wieczorek-Tomaszewska, M. (2013). Innowacyjne uczenie dla efektywnego uczenia się. Dydaktyka cyfrowa epoki smartfona, Analiza cyfrowych aspektów dydaktyki gimnazjum $i$ szkoły średniej. Wieczorek-Tomaszewska, M. (Ed.), Kraków: Wydawca SMWI. 